\title{
Expression of Enzymes During the Germination of Seeds in Endangered Cerrado Species
}

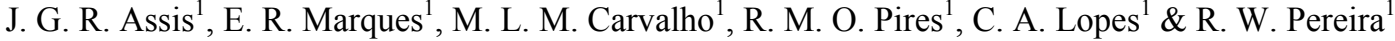 \\ ${ }^{1}$ Department of Agriculture, Universidade Federal de Lavras, Lavras, MG, Brazil \\ Correspondence: Raquel Maria de Oliveira Pires, Department of Agriculture, Universidade Federal de Lavras, \\ MG, 37200-000, Brazil. Tel: 55-0353-8291-319. E-mail: raquel.mopires@gmail.com
}

Received: December 8, 2018

Accepted: January 19, 2019

Online Published: May 15, 2019

doi:10.5539/jas.v11n6p469

URL: https://doi.org/10.5539/jas.v11n6p469

\begin{abstract}
The objective of this study was to evaluate the enzymes expression during the seeds germination process of ever-lasting species Comanthera elegans and Comanthera bisulcata. For the evaluation of the seeds physiological potential, the germination test and index of germination speed were performed. The expression of enzymes esterase (EST), malate dehydrogenase (MDH), alcohol dehydrogenase (ADH), superoxide dismutase (SOD), catalase (CAT) and endo- $\beta$-mannanase during the germination process were evaluated. The expression of these enzymes was evaluated in dried seeds, in the protrusion, in the emergence of the primal leaf, at the beginning of the formation of normal seedling and dormant seeds at the end of the germination process. To the extent that the germination process occurs in the species $C$. bisulcata and C. elegans there is greater expression of the enzyme CAT and lower of the enzyme EST. There is variation in the expression of the enzymes SOD, $\mathrm{ADH}$ and $\mathrm{MDH}$ in seeds of both species during the germination process. The enzyme endo- $\beta$-mannanase presents greater activity in seeds with radicle protrusion in the two studied species.
\end{abstract}

Keywords: enzymatic activity, Comanthera elegans, Comanthera bisulcata

\section{Introduction}

The plants known as everlasting, of the species Comanthera elegans (Bong.) Parra and Giul and Comanthera bisulcata (Koern.) L.R.Parra \& Giul, belong to the Eriocaulaceae family (Parra et al., 2010). Of natural occurrence in Brazil in the rupestrian fields, mainly in the region of Diamantina, MG, they have great commercial interest for its population, due to the fact of the flowers to be harvested, to conserve the color and shape for a long period. Due to the disorderly extractivism by presenting high value mainly in the international market, the roots are pulled up along with the scapes and flowers before the seeds formation, thus leaving a minimum number of individuals in the areas, which makes it inviable not only their regeneration but also the production of new seeds. Some species of this genus, as for example the Comanthera elegans, are included in the list of endangered species (Brazil, 2014). Thus, it becomes necessary to carry out measures to guarantee their conservation.

There is a great interest in the study on the livelihood strategies of everlasting plants, which comprise since the seeds development until the formation of the adult plant. Therefore, it is of fundamental importance the knowledge of the germination process in which metabolic changes occur in the embryo until the seedling formation. In addition to extrinsic factors related to germination, the intrinsic ones must be also considered as the enzymes expression during this process.

Several authors have observed low physiological quality in everlasting seeds. Oliveira et al. (2015) affirm that the highest rate of germination of C. elegans, at a temperature of $25 \pm 2{ }^{\circ} \mathrm{C}$, was $22.932 \%$ for seeds collected in the month of September. In the collections in the periods that precede or follow this month, the percentage of germination did not surpass $11.72 \%$. Still the same authors affirm that the germination results vary with the day of harvest, with the site and with the flowering. There is, however, the need to study the causes which observed a low physiological quality, which can be elucidated by means of studies of enzyme expression.

In the case of seeds, the study of enzyme expression has helped in the understanding of the biochemical processes that are associated with their quality. As an example, one may mention the enzymes that participate in the reactions of lipid oxidation as the esterases (Rejon et al., 2012). There are also those who act in breathing as 
the malate dehydrogenase and alcohol dehydrogenase (Tunes et al., 2011) and even the enzymes with antioxidant function as the catalase and superoxide dismutase (Wang et al., 2015).

Thus, identifying the enzymes that are involved in the metabolic reactions responsible for the synthesis and degradation of molecules, can provide subsidies to understand the mechanisms involved in seed germination, as the activities related to the biochemical processes.

In this context, the objective of this study was to evaluate the enzymes expression during the germination process of ever-living species seeds Comanthera elegans and Comanthera Bisulcata, using the electrophoresis technique.

\section{Material and Methods}

The collection of the inflorescences of ever-living plants (Comanthera elegans and Comanthera bisulcata) was performed in the city of Diamantina, MG between the months of May to August 2015 at representative locations of the production area.

For the seeds extraction inflorescences were selected with the entire flower head opened that were crushed in a blender for 30 seconds, removing all inert material with the aid of sieves to obtain the pure seed. The determination of water content was obtained by the oven method at $130^{\circ} \mathrm{C}$ for 1 hour, using two replications of $0.1 \mathrm{~g}$ for each species (MAPA, 2009). The germination test was conducted with four replications of 100 seeds, with sowing in germination blotter paper soaked with distilled water in a proportion of 2.5 times the weight of the paper and placed in gerbox-type plastic boxes. The seeds remained in BOD during 35 days in alternating temperature of $25^{\circ} \mathrm{C} / 16$ hours in the presence of light and $15^{\circ} \mathrm{C} / 8$ hours in the dark for the species Comanthera elegans according to Pereira et al. (2014) and to Comanthera bisulcata was $20^{\circ} \mathrm{C} / 16$ hours in the presence of light and $15{ }^{\circ} \mathrm{C} / 8$ hours in the dark according to Oliveira and Garcia (2011). The results were expressed as mean percentage of normal seedlings. For the seeds remaining from the germination test, the tetrazolium test was performed for the determination of its viability in a solution containing $0.5 \%$ of $2,3,5$ triphenyl tetrazolium chloride for 3 hours, in the dark, at a temperature of $30^{\circ} \mathrm{C}$. The evaluation was performed with the aid of stereoscopic microscope.

The germination speed index was performed together with the germination test, by daily counts of the number of seeds with radicle protrusion until the end of the germination test and index calculated according to Maguire (1962).

The evaluation of the enzyme expression was carried out during the germination process by means of the technique of electrophoresis. To obtain seeds and normal seedlings at different stages of the germination process, these were sown on paper substrate and classified as: (1) dry seed (S), (2) beginning of the protrusion (Pro), (3) emergence of the primary leaf (FP), (4) beginning of the formation of normal seedlings (Plt) and (5) dormant seeds at the end of the germination process (SD).

The obtaining of seed and the normal seedlings in the 4 phases were respectively at $6,9,20$ and 35 days after soaking for C. elegans and 9, 13, 25 and 35 days for C. bisulcata. To obtain a total volume of $100 \mathrm{mg}$ of seeds and seedlings, several sowings were carried out. The seeds and normal seedlings were stored in deep freezer (-86 $\left.{ }^{\circ} \mathrm{C}\right)$ for the electrophoretic analyzes.

For the extraction of enzymes $100 \mathrm{mg}$ of seeds and seedlings were macerated in the presence of polyvinylpyrrolidone (PVP) and liquid nitrogen. $250 \mu \mathrm{l}$ of extraction buffer were added (Tris-HCl, $\mathrm{pH} 8.0$ ) and $0.1 \%$ of $\beta$-mercaptaenol, were maintained "overnight" and then centrifuged at $14000 \mathrm{rpm}$ for 30 minutes at $4{ }^{\circ} \mathrm{C}$. Out of the supernatant $60 \mu \mathrm{L}$ was removed with subsequent application in polyacrylamide gel $7.5 \%$ (separator gel) and $4.5 \%$ (GEL CONCENTRADOR). The gels were revealed according to the methodology described by Alfenas (2006).

For analysis of the enzymatic activity of endo- $\beta$-mannanase in each $100 \mathrm{mg}$ of powder of each sample $300 \mu \mathrm{L}$ of extraction buffer were added [0.1 M Hepes $/ 0.5 \mathrm{M} \mathrm{NaCl}$ and ascorbic acid $(5 \mathrm{mg}$ of ascorbic acid per $\mathrm{ml}$ of buffer, $\mathrm{pH}$ 8.0]. The samples were centrifuged for 30 minutes at $14000 \mathrm{rpm}$ and $2 \mu \mathrm{L}$ of supernatant applied in gel containing $6 \mathrm{~mL}$ of LBG(locust bean gum), $0.24 \mathrm{~g}$ of agarose and $24 \mathrm{~mL}$ of buffer $\mathrm{pH} 5.0$ (1 M Citric Acid/0.4 M of $\mathrm{Na}_{2} \mathrm{HPO}_{4} \cdot 2 \mathrm{H}_{2} \mathrm{O}$ ). The aliquots were applied in $2 \mathrm{~mm}$ holes made in the gel using an awl. The gel was incubated for $21 \mathrm{~h}$ and revealed according to the methodology proposed by Silva et al. (2004). The measurement of the halos diameter in two directions was performed with the aid of the Software Image ${ }^{\circledR}$ resulting in an average and a comparison was made with the standard curve generated by endo- $\beta$-mannanase enzyme of Aspergillus niger (Megazyme). The calculation of the activity of the enzyme endo- $\beta$-mannanase was performed according to Downie et al. (1994). 
The interpretation of the results was based on a qualitative analysis of the electrophoresis gels, considering the presence/absence, as well as the intensity of each one of the electrophoretic bands in each iso-enzymatic system evaluated. For the quantitative analysis of the bands the image analysis Software ImageJ (Rasband, 1997) was used measured in pixel $^{2}$. This software has been specially developed to measure the isoforms contained in each of the trenches.

\section{Results and Discussion}

The water content of the seeds of the species $C$. bisulcata and $C$. elegans were $9 \%$ and $7 \%$, indicating that they are richer in oil seeds, as they reach the point of hygroscopic equilibrium with lower levels of water, under temperature conditions of $25^{\circ} \mathrm{C}$ and relative humidity of $60 \%$. Some authors have observed the same behavior in oilseeds as Antoniassi et al. (2013) and sesame, Faugno, et al. (2016).

According to the results in Table 1, variation is observed between the two species for the evaluated physiological quality by means of the germination test and GVI. Superior values of germination and GVI were observed in seeds of the species $C$. elegans comparing to $C$. bisulcata. For the results of the tetrazolium test at the end of the germination test, it was observed that the remaining seeds were not viable (Table 1).

Table 1. Average values of hard seeds, dormant, dead and of normal seedlings obtained from the germination test $(\%)$, and germination speed index (GSI) of everlasting seeds

\begin{tabular}{llllll}
\hline \multirow{2}{*}{ Species } & \multirow{2}{*}{ Normal seedlings (\%) } & \multicolumn{4}{c}{ Seeds (\%) } \\
\cline { 3 - 5 } & & Hard & Dormant & Dead \\
\hline C. bisulcata & 25 & 0 & 1 & 74 & 5.21 \\
C. elegans & 46 & 0 & 0 & 54 & 9.68 \\
\hline
\end{tabular}

Similar results regarding the low percentage of germination in everlasting seeds were found in the work of Garcia et al. (2014); Oliveira et al. (2015). These low germination results are expected since many authors have highlighted some aspects such as: climate variation that can influence the beginning and end of the harvest, the physiological state in which the seed is, the period of maturation or could be by climatic conditions and/or edaphic micro conditions of the place in where the plants developed in which seeds were produced (Oliveira \& Garcia, 2011).

Oliveira et al. (2015) while studying the collection period of C. elegans, stated that collections before May, the seeds germination rates were below 50\%. These results agree with those found in the literature and prove that the collection of inflorescences occurs before the period of seeds formation and that only a small portion of these can achieve the physiological maturity.

By electrophoretic analysis of the enzyme esterase (EST) (Figure 1), a higher expression was observed in dried seeds with small concentration differences in the two species (1643 and 1547 pixel $\left.^{2}\right)$. For C. bisulcata there was a gradual decrease of EST along the germinative process and for the species C. elegans a more pronounced decrease was observed. 


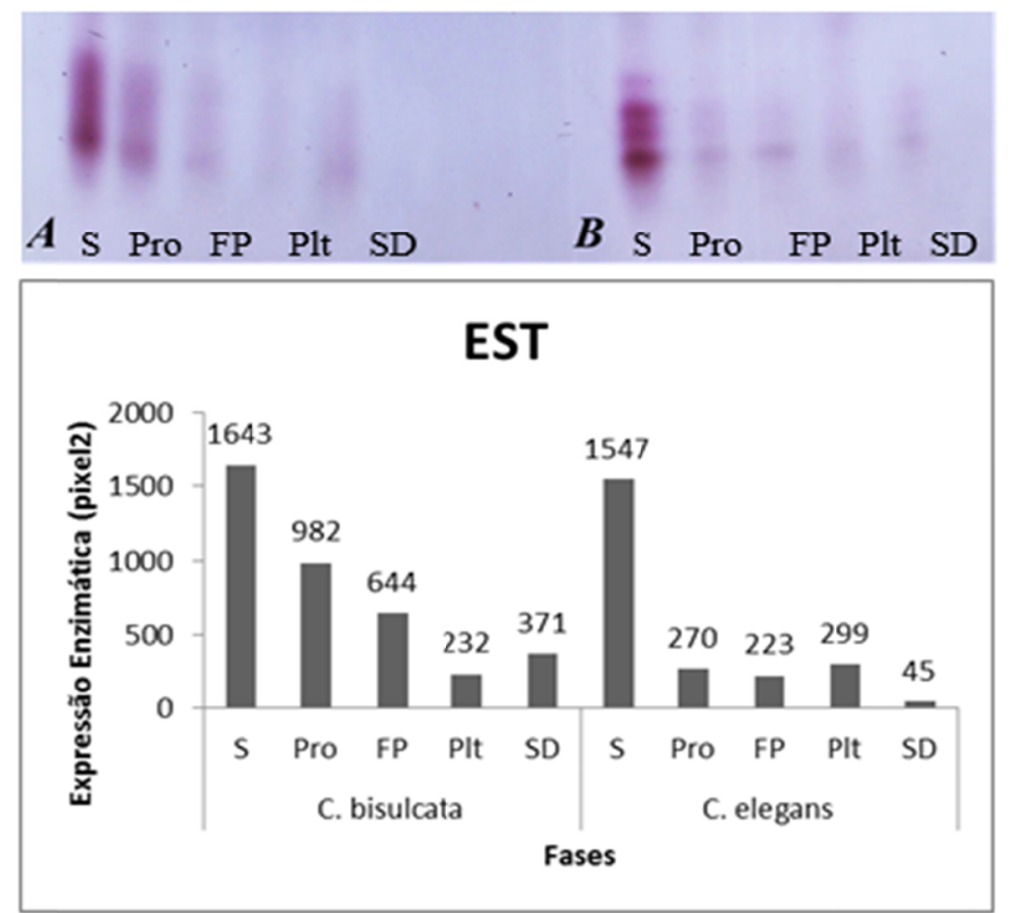

Figure 1. Expressions of the enzyme esterase (EST) in everlasting seeds, of the species $C$. bisulcata (A) and $C$. elegans (B), in the different phases during the germination process. (S) dried seeds, (Pro) protrusion, (FP) emergence of primary leaf(Plt) beginning of the formation of normal seedling and dormant seeds (SD)

The decrease in the EST activity, in both species along the germinative process, can be tied to the fact that this enzyme is related to the lipids degradation. The ESTs represent a large group of enzymes, with a minimum of 20 , that catalyze the breakdown of esters bonds. This process is important for the resumption of growth of the embryonic axis (Rudakova et al., 2016).

The mobilization of triglycerides in plants is observed mainly in the seeds to stimulate growth after germination (Kelly \& Feussner, 2016).

The greatest expressions of the enzyme catalase (CAT) were observed in seedlings of two species (1270 and 1521 pixel $^{2}$ ) in relation to the other phases (Figure 2). During the germination process there was a gradual increase of the expression of CAT in the species C. bisulcata, while in C. elegans there was variation. Lower CAT enzyme activity was observed in dormant seeds, probably due to the low metabolism. In the species $C$. elegans greater expression was observed, in relation to the different stages of the germination process, mainly originated from the radicle protrusion, while in C. bisulcata was on the primary leaf. 

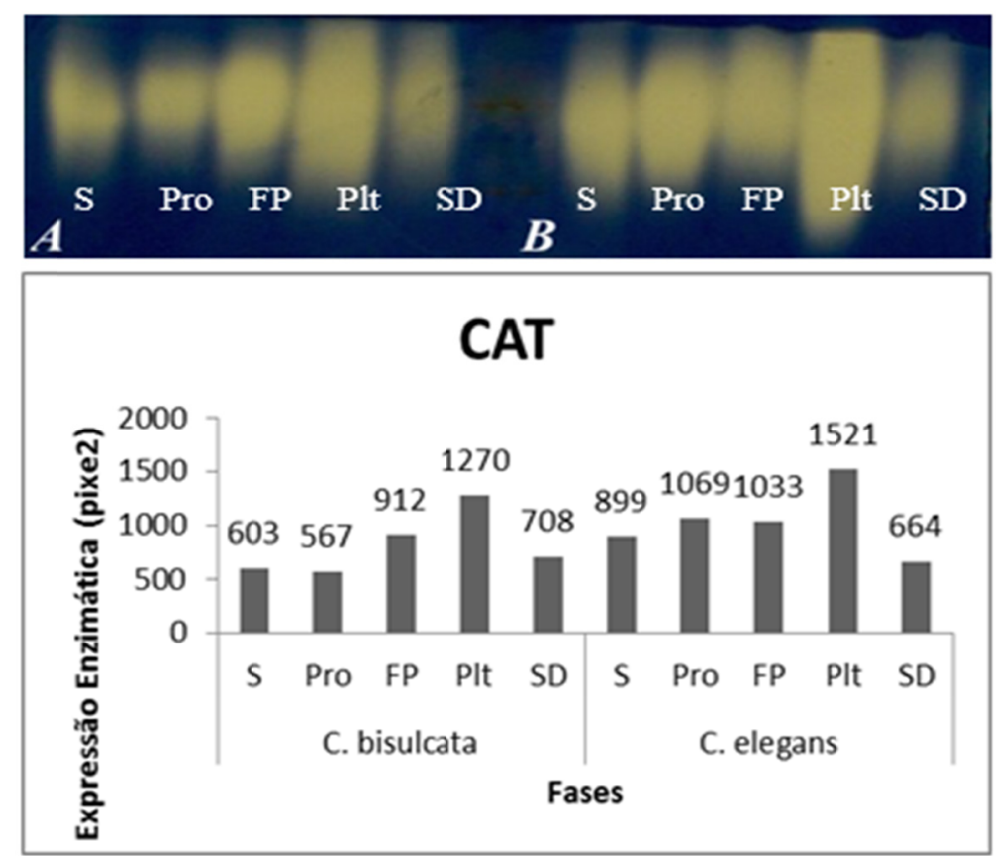

Figure 2. Expressions of the enzyme catalase (CAT) in everlasting seeds, of the species $C$. bisulcata (A) and C. elegans (B), in the different phases during the germination process. (S) dried seeds, (Pro) protrusion, (FP) emergence of primary leaf(Plt) beginning of the formation of normal seedling and dormant seeds (SD)

The high expression of catalase enzyme in seedlings of two species may be related to the action of this enzyme to act efficiently in the elimination of reactive oxygen enzymes, the EROs, which increases the capacity of protection against oxidative stress.

Similar results were found by Feng et al. (2011) during the germination of seeds of Jatropha curcas and observed that the amount of CAT present in aerobic cells is directly proportional to the oxidative state of the cells, i.e., the increase in enzyme activity of CAT is probably involved with the defense mechanism of $\mathrm{J}$. curcas seedlings against oxidative stress during germination.

Concerning the enzyme superoxide dismutase (SOD) at different stages of germination, it is possible to observe higher expression for the species C. bisulcata in seeds with root protrusion and for C. elegans in seedlings (1138 and 5098 pixel $^{2}$ ). During the germination process, in the species C. bisulcata there was a decrease in the expression of SOD in a progressive way, while in C. elegans there was a gradual increase in seeds with root protrusion and with primordial leaf with a sharp increase in the concentration of this enzyme in seedlings (Figure $3)$. 

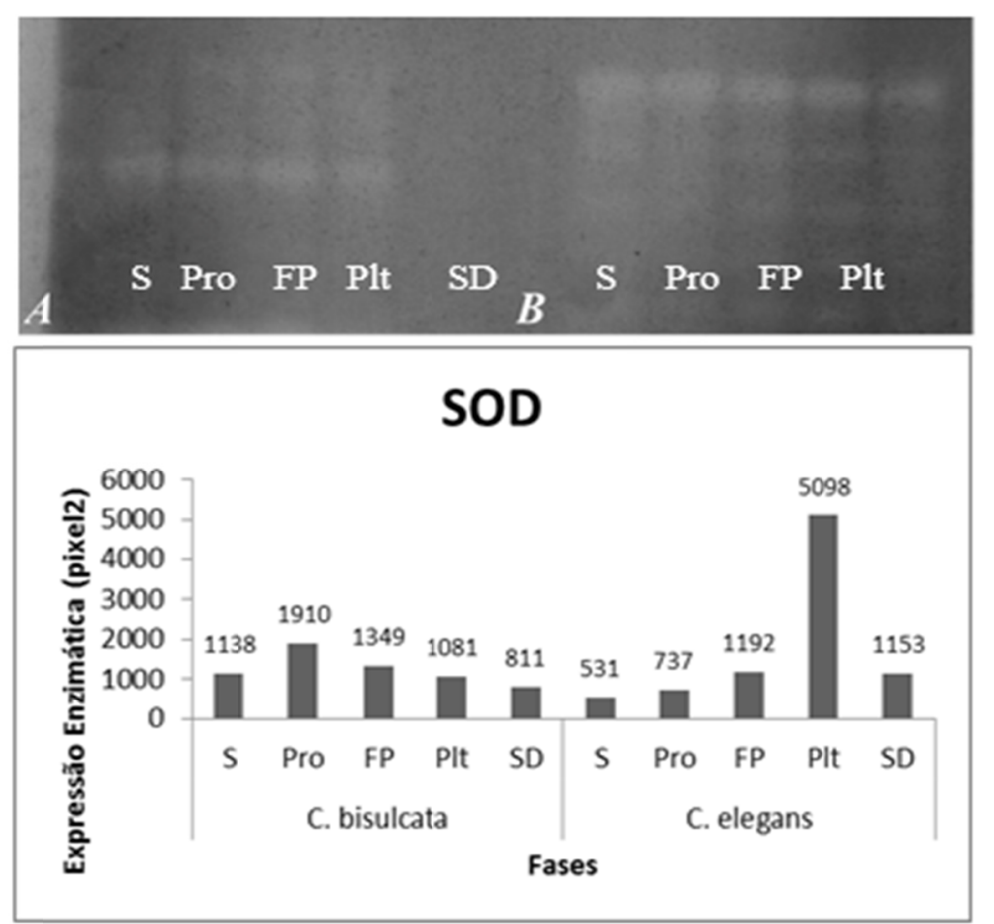

Figure 3. Expressions of the enzyme superoxide dismutase (SOD) in everlasting seeds, of the species $C$. bisulcata (A) and C. elegans (B), in the different phases during the germination process (S) dried seeds, (Pro) protrusion, (FP) emergence of primary leaf (Plt) beginning of the formation of normal seedling and (SD) dormant seeds

Differences in the physiological quality of seed observed may contribute to variations in the enzymatic expression. According to Pisoschi and Pop (2015), the first types of antioxidant action are against oxidants, are those that are ROS and also those that block and capture radicals that are formed.

The presence of antioxidant enzymes in dried seeds and its activation during germination represents a metabolic adaptation that leads to the development and preparation of seeds for reactions that occur during the germination after radicle protrusion (Wojtyla et al., 2006).

Greater expressions of CAT and SOD enzymes were observed in seedlings of the species C. elegans which can be due to the fact of being involved in the preservation of seed and also protection against the EROs in cells and tissues of seeds and seedlings during the germination process.

Greater expressions of the enzyme malate dehydrogenase (MDH) in both species were found in seedlings (4503 and 6447 pixel $^{2}$ ). It is noted that in the species C. bisulcata the expression of MDH increases gradually and in $C$. elegans it varied (Figure 4). 


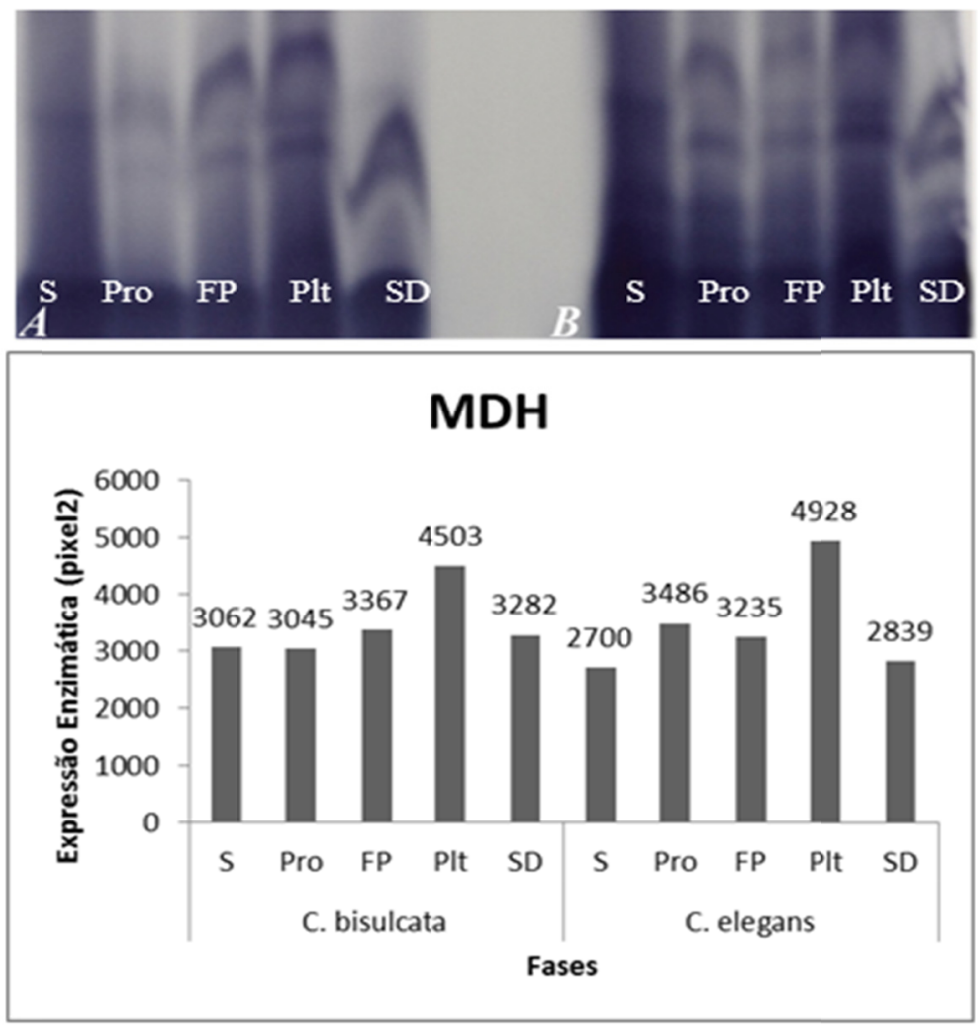

Figure 4. Expressions of the enzyme malate dehydrogenase (MDH) in everlasting seeds, of the species $C$. bisulcata (A) and C. elegans (B), in the different phases during the germination process. (S) dried seeds, (Pro) protrusion, (FP) emergence of primary leaf(Plt) beginning of the formation of normal seedling and dormant seeds (SD)

The fact that the expression of MDH enzyme have been considerably higher in C. elegans can be explained by the fact that such species has a greater vigor and germination percentage according to the GVI, and the germination test.

Similar results were found by Santos et al. (2016) who upon studying the physiological quality of maize seeds through the respiratory enzyme activity stated that vigorous seeds breathe more compared to those less vigorous, which have a high consumption of $\mathrm{O}_{2}$ and consequently an increase in the production of $\mathrm{CO}_{2}$.

Another enzyme involved in the breathing process is the alcohol dehydrogenase (ADH). The greatest expression of this enzyme was observed in seeds that were not soaked of the two species, i.e., in dried seeds which is related to the anaerobic respiration. In dried seeds of the species C. elegans there are isoforms that in C. bisulcata disappeared. During the germination process, the expression of the enzyme ADH varies both in relation to the two species as in the phases that the seeds and seedlings were (Figure 5). 


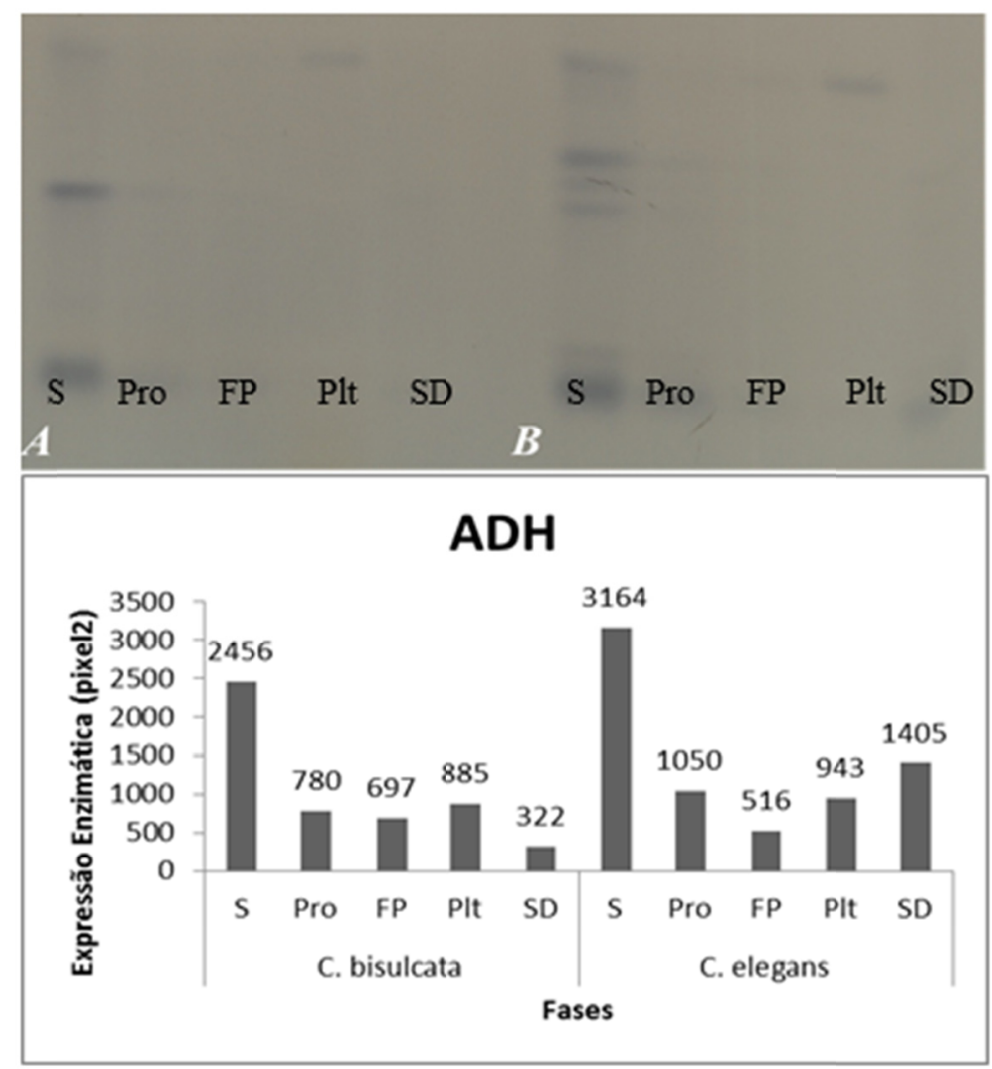

Figure 5. Expressions of the enzyme alcohol dehydrogenase (ADH) in everlasting seeds, of the species $C$. bisulcata (A) and C. elegans (B), in the different phases during the germination process. (S) dried seeds, (Pro) protrusion, (FP) emergence of primary leaf(Plt) beginning of the formation of normal seedling and dormant seeds $(\mathrm{SD})$

The fact that the greatest expression of the enzyme observed in this study is in dried seeds, can be attributed to lack of oxygen available, thus favoring the route of anaerobic respiration. To the extent that the process of seed soaking occurs, the oxygen supply is observed justifying the reduction of enzymatic activity of ADH.

Concerning the activity of the enzyme endo- $\beta$-mannanase, not only in species $C$. bisulcata as in $C$. elegans, it is possible to verify greater expression in the protrusion phase $\left(848\right.$ and $\left.887 \mathrm{pmol} \mathrm{min} 1 \mathrm{~g} \mathrm{~g}^{-1}\right)$ and lower in seedlings (51 and $2.0 \mathrm{pmol} \min 1 \mathrm{~g}^{-1}$ ). In the species $C$. bisulcata the concentration of this enzyme decreases more sharply in the protrusion phase for primary leaf, while in C. elegans the decrease is observed in the phase of primary leaf for seedling (Figure 6). The size of the alos observed in Figure 8 is indirectly proportional to the expression of the enzyme endo- $\beta$-mannanase. 


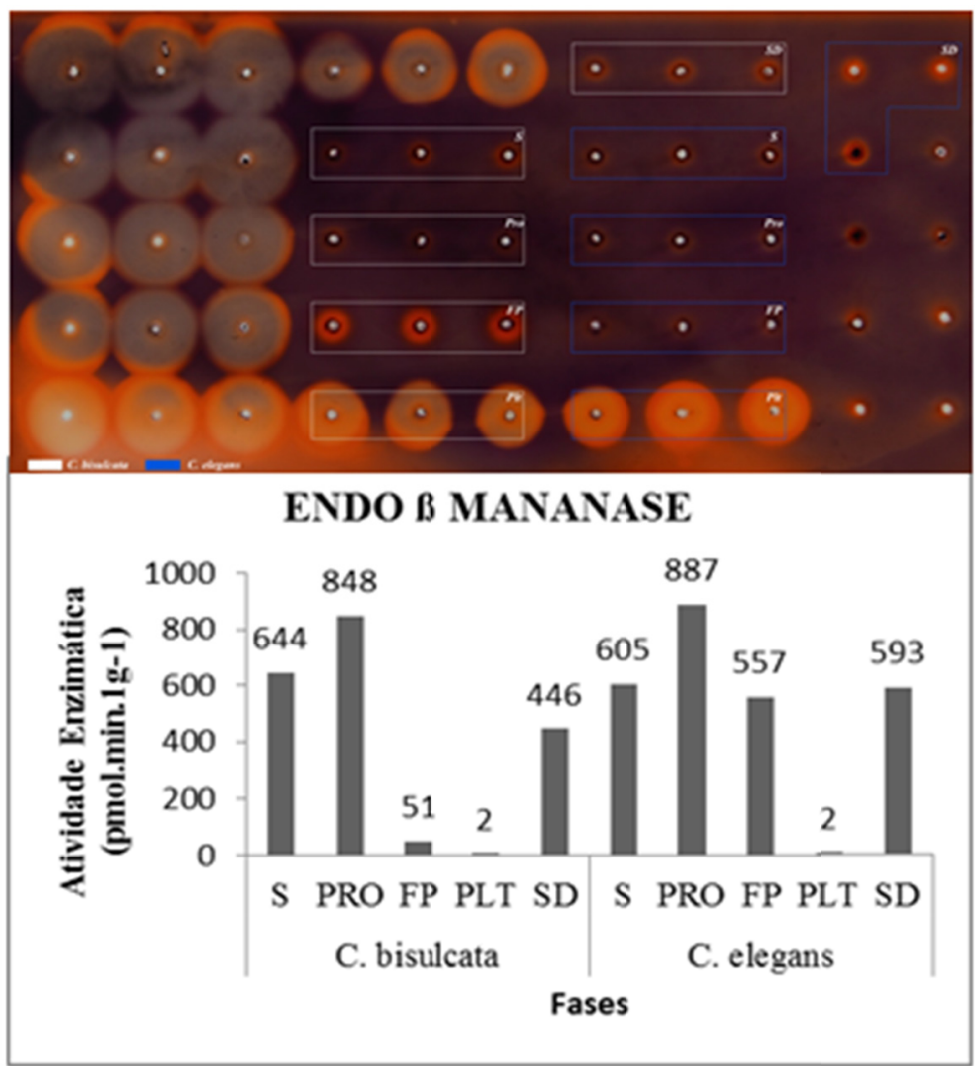

Figure 6. Expressions of the enzyme endo- $\beta$-mannanase in everlasting seeds, of the species $C$. bisulcata $(\mathrm{A})$ and C. elegans (B), in the different phases during the germination process. (S) dried seeds, (Pro) protrusion, (FP) emergence of primary leaf(Plt) beginning of the formation of normal seedling and dormant seeds (SD)

Similar results were found by Farias et al. (2015) upon studying the expression in embryos and micropillar endosperm during the germination in coffee seeds. These authors observed an increase of enzyme activity during the seeds soaking and affirm that the enzyme endo- $\beta$-mannanase plays an important role in the weakening of endosperm cell walls.

In a study conducted by Catão et al. (2014) with lettuce seeds it was verified that the increase of the activity of endo- $\beta$-mannanase was associated with the weakening of the endosperm under high temperatures, leading the seed to germination. Thus, it should be pointed out in this study that the highest enzymatic activity in the pattern of the enzyme endo- $\beta$-mannanase was observed in seeds with radicle protrusion, which in turn is responsible for the endosperm degradation in the seeds germination.

\section{Conclusions}

There is an increase in enzyme expression CAT and reduction of the enzyme EST throughout the germination process of the seeds of the species C. bisulcata and C. elegans.

The expression of the enzyme endo- $\beta$-mannanase is higher in seeds of the species $C$. bisulcata and $C$. elegans in the root protrusion phase.

There is variation in the expression of the enzymes $\mathrm{SOD}, \mathrm{ADH}$ and $\mathrm{MDH}$ in seeds of the species $C$. bisulcata and C. elegans during the germination process.

\section{Funding Sources and acknowledgments}

To CNPq, CAPES, Fapemig and Universidade Federal de Lavras.

\section{References}

Abreu, L. A. D. S., Carvalho, M. L. M., Pinto, C. A. G., Kataoka, V. Y., \& Silva, T. T. D. (2013). Deterioration of sunflower seeds during storage. Journal Seed Science, 35, 240-247. https://doi.org/10.1590/S231715372013000200015 
Alfenas, A. C. (2006). Eletroforese e marcadores bioquimicos em plantas e microrganismos (2nd ed., p. 627). UFV, Viçosa.

Antoniassi, R., Arriel, N. H. C., Gonçalves, E. B., Freitas, S .C., Zanotto, D. L., \& Bizzo, H. R. (2013). Influência das condições de cultivo na composição da sementee do óleo de gergelim. Revista. Ceres, 60 , 301-310. https://doi.org/10.1590/S0034-737X2013000300001

Brasil. (2014). Portaria $n^{\circ}$ 443, de 17 de dezembro de 2014 (p. 110). Diário oficial [da] República Federativa do Brasil, Poder Executivo, Brasília, DF.

Catão, H. C. R. M., Gomes, L. A. A., dos Santos, H. O., Guimarães, R. M., Fonseca, P. H. F., \& Caixeta, F. (2014). Aspectos fisiológicos e bioquímicos da germinação de sementes de alface em diferentes temperaturas. Pesquisa Agropecuária Brasileira, 49, 316-322. https://doi.org/10.1590/S0100-204X201400 0400010

Downie, B., Hillhorsth, W. M., \& Bewley J. D. A. (1994). New assay for quantifying endo- $\beta$-D-mannanase activity using Congo red dye. Phytochemistry, 36, 829-835. https://doi.org/10.1016/S0031-9422(00) 90446-1

Farias, E. T., Silva, E. A., Toorop, P. E., Bewley, J. D., \& Hilhorst, H. W. (2015). Expression studies in the embryo and the micropylar endosperm of germinating coffee (Coffee arábica cv. Rubi) seeds. Plant Growth Regulation, 75, 575-581. https://doi.org/10.1007/s10725-014-9960-6

Faugno, S., Luisa del Piano, L., Crimaldi, M., Ricciardiello, G., \& Maura Sannino, M. (2016). Mechanical oil extraction of Nicotina tabacum L. seeds: Analysis of main extration parameters on oil yield. Journal of Agricultural Engineering, 47, 142-147. https://doi.org/10.4081/jae.2016.539

Feng, C., LanJu, M., Xiao, L. A., Shun, G., Lin, T., \& Fang, C. (2011). Lipid peroxidation and antioxidant responses during seed germination of Jatropha curcas. International Journal of Agriculture and Biology, 13, 25-30.

Garcia, Q. S., Oliveira, P. G., \& Duarte, D. M. (2014). Seasonal changes in germination and dormancy of buried seeds of endemic Brazilian Eriocaulaceae. Seed Science Research, 24, 113-117. https://doi.org/10.1017/ S0960258514000038

Kelly, A., \& Feussner, I. (2016). Oil is on agenda: Lipid turnover in higher plants. Molecular and Cell Biology of Lipids, 1861, 1253-1268. https://doi.org/10.1016/j.bbalip.2016.04.021

Maguire, J. D. (1962). Speed of germination aid in selection and evaluation for seedling emergence and vigor. Crop Science, 2, 176-177. https://doi.org/10.2135/cropsci1962.0011183X000200020033x

MAPA (Ministério da Agricultura, Pecuária e Abastecimento). (2009). Regras para análise de sementes (p. 399). Brasília: MAPA/ACS.

Martinelli, G., \& Moraes, M. A. (2013). Vermelho da Flora do Brasil (pp. 496-501). Andrea Jakobsson: Instituto de Pesquisas Jardim Botânico do Rio de Janeiro.

Oliveira, M. N. S., Dias, B. A. S., Andrade, G. C., Tanaka, M. K., Avila, R. G., \& Silva, L. C. (2015). Harvest times of Comanthera elegans, a worldwide traded Brazilian species of everlasting flower: Implications on seed production, germination, and on species management. Brazilian Journal of Botany, 38, 795-808. https://doi.org/10.1007/s40415-015-0179-1

Oliveira, P. G., \& Garcia, Q. S. (2011). Germination characteristics of Syngonanthus seeds (Eriocaulaceae) in campos rupestres vegetation in south-eastern Brazil. Seed Science Research, 21, 39-45. https://doi.org/ $10.1017 / \mathrm{S} 0960258510000346$

Parra, L. R., Giulietti, A. M., Andrade, M. J. G., \& Van Den Berg, C. (2010). Reestablishment and new circumscription of Comanthera (Eriocaulaceae). Taxon, 59, 1135-1146. https://doi.org/10.1002/tax.594013

Pisoschi, A. M., \& Pop, A. (2015). The role of antioxidants in the chemistry of oxidative stress: A review. European Journal of Medicinal Chemistry, 97, 55-74. https://doi.org/10.1016/j.ejmech.2015.04.040

Rejon, J. D., Zienkiewicz, A., Rodríguez-García, M. I., \& Castro, A. J. (2012). Profiling and functional classification of esterases in olive (Olea europaea) pollen during germination. Annals of Botany, 110, 1035-1045. https://doi.org/10.1093/aob/mcs174 
Rudakova, A. S., Rudakov, S. V., Davydova, N. V., Mirskaya, G. V., Zhuravleva, E. V., \& Chesnokov, Y. V. (2016). Isozymic analysis of esterases in mature seeds of hexaploid soft wheat (Triticum aestivum L.), Agricultural Biology, 51, 327-334. https://doi.org/10.15389/agrobiology.2016.3.327eng

Santos, H. O., Von Pinho, I. V., Oliveira Pires, R. M., Silva, V. I. F., Carvalho, M. L. M., \& Oliveira, R. M. E. (2016). Physiological quality of hybrid maize seeds through respiratory and enzymatic activities. African Journal of Agricultural Research, 11, 1879-1886. https://doi.org/10.5897/AJAR2015.10457

Taiz, L., \& Zeiger, E. (2013). Fisiologia Vegetal (5th ed., p. 954). Porto Alegre: Artmed.

Tunes, L. M., Badinelli, P. G., Barros, A. C. S. A., Meneghello, G. E., \& Amarante, L. (2011). Influência dos diferentes períodos de colheita na expressão de isoenzimas em sementes de cevada. Revista. Ceres, 58, 178-184. https://doi.org/10.1590/S0034-737X2011000200008

Wang, W. Q., Liu, S. J., Song, S. Q., \& Moller, I. M. (2015). Proteomics of seed development, desiccation tolerance, germination and vigor. Plant Physiology and Biochemistry, 86, 1-15. https://doi.org/10.1016/ j.plaphy.2014.11.003

Wojtyla, L., Garnczarska, M., Zalewski, T., Bednarski, W., Ratajczak, L., \& Jurga, S. (2006). A comparative study of water distribution, free radical production and activation of antioxidative metabolism in germination pea seeds. Journal of Plant Physiology, 163, 1207-1220. https://doi.org/10.1016/j.jplph. 2006.06.014

\section{Copyrights}

Copyright for this article is retained by the author(s), with first publication rights granted to the journal.

This is an open-access article distributed under the terms and conditions of the Creative Commons Attribution license (http://creativecommons.org/licenses/by/4.0/). 